\title{
ERROR FACTI PADA PEMBUKTIAN ILLEGAL FISHING DITINJAU DARI HUKUM ISLAM
}

\author{
Fifin Inbatun Hasanah \\ fifin_inbatun@yahoo.com \\ Berbek 3 RT 003 RW 003 Waru Sidoarjo
}

\begin{abstract}
This article highlights the meanings of evidence used to describe the right in front of court in the form of either testimony, witness, or variety of indications that can be used as a guideline by judge to restore the right to its owner. In line with the decision No. 84 PK/Pid/2005 that legal consideration of judex facty of the Court of Gresik, the High Court and the Supreme Court of Surabaya did not consider the result of evidence revealed at the first hearing in the Court of Gresik. A public prosecutor also could not prove who is the real shipowner based on the vessel proofs. This ruling is not appropriate because in term of proof at trial, a public prosecutor should be able to bring witnesses of the shipowner used by the defendant. This is, of course, to determine whether or not anyone who asked or ordered the defendant to do something illegal fishing by transferring, loading, and purchasing the illegal fishing. This is not in accordance with al-Qur'an chapter al-Baqarah verse 282, and al-Talâq verse 2 .
\end{abstract}

Keywords: Islamic law, verdict, evidence, illegal fishing.

Abstrak: Pembuktian merupakan segala sesuatu yang dapat digunakan untuk menjelaskan yang hak (benar) di depan majelis hakim, baik berupa keterangan, saksi, dan berbagai indikasi yang dapat dijadikan pedoman oleh majelis hakim untuk mengembalikan hak kepada pemiliknya. Dalam kasus putusan Nomor: 84 PK/Pid/2005, bahwa pertimbangan hukum judex facty Pengadilan Negeri Gresik, Pengadilan Tinggi Surabaya dan Mahkamah Agung sama sekali tidak mempertimbangkan hasil pembuktian yang terungkap di persidangan tingkat pertama (Pengadilan Negeri Gresik), termasuk Jaksa Penuntut Umum sama sekali tidak dapat/tidak sanggup membuktikan siapa pemilik kapal yang sesungguhnya sesuai suratsurat bukti. Putusan ini kurang tepat, karena dalam hal pembuktian di Persidangan, seorang Jaksa Penuntut Umum seharusnya dapat menghadirkan saksi pemilik kapal yang dipakai oleh terdakwa, untuk mengetahui benar tidaknya siapa yang menyuruh dan atau memerintahkan terdakwa untuk melakukan perbuatan illegal fishing dengan mentransfer, pemuatan, dan pembelian ikan yang tidak sah. Hal ini tidak sesuai dengan al-Qur'an Surat al-Baqarah ayat 282, dan surat al-Thalaq ayat 2.

Kata Kunci: Hukum Islam, putusan, pembuktian, illegal fishing 


\section{Pendahuluan}

Kegiatan penangkapan ikan yang melanggar hukum (illegal fishing) hingga hari ini masih merupakan persoalan yang cukup serius dan menjadi bentuk gangguan keamanan sumberdaya laut, berdampak buruk bagi terbangunnya pengelolaan pesisir dan laut secara lestari.

Terdapat beberapa faktor yang mempengaruhi sehingga terjadinya kegiatan penangkapan yang illegal, misalnya, telah terjadinya over fishing di negara-negara tetangga yang kemudian mencari daerah tangkapan di Indonesia untuk memenuhi kebutuhan produksi dan pemasarannya. Didukung dengan sistem penegak hukum di laut kita masih sangat lemah, tidak sebanding antara luas laut dan kekuatan yang ada, sehingga para pelanggar leluasa dalam melaksanakan kegiatannya.

Selain itu salah satu bentuk illegal fishing yang terjadi adalah penangkapan ikan oleh kapal-kapal asing atau yang berbendera Indonesia di perairan nusantara dengan berbagai modus operandi, seperti tanpa dokumen izin, pelanggaran daerah penangkapan (fishing ground), menyalahi ketentuan alat tangkap, melabuhkan hasil tangkapannya di negara lain. ${ }^{1}$

Sebagaimana tercantum dalam Pasal 40 ayat (2) UU No. 21 Tahun 1992 Tentang Pelayaran, bahwa setiap kapal yang akan berlayar wajib memiliki Surat Izin Berlayar yang dikeluarkan oleh syahbandar setelah memenuhi persyaratan kelaiklautan kapal. ${ }^{2}$

Yang disebut dengan membuktikan adalah meyakinkan Majelis Hakim tentang dalil-dalil yang dikemukakan dalam suatu persengketaan, atau menurut pengertian yang lain adalah kemampuan penggugat atar tergugat memanfaatkan hukum pembuktian untuk mendukung dan membenarkan hubungan hukum dan peristiwa-peristiwa yang didalilkan (dibantahkan) dalam hubungan hukum yang diperkarakan. ${ }^{3}$

Pembuktian menurut pemahaman umum adalah menunjukkan ke hadapan tentang suatu keadaan yang bersesuaian dengan induk

\footnotetext{
1Andi Iqbal Burhanuddin, "Detik News", http://info--budidaya.blogspot.com/2012/03/illegalfishing-antara-kesadaran-dan.html. (16 Desember 2012)

${ }^{2}$ UU No. 21 Tahun 1992 Tentang Pelayaran

3 Ahmad Mujahidin, Pembaharuan Hukum Acara Peradilan Agama (Bogor: Ghalia Indonesia, 2012), 173.
} 
persoalan, atau dengan kata lain adalah mencari kesesuaian antara peristiwa induk dengan akar-akar peristiwanya. ${ }^{4}$

Dalam hukum acara perdata, salah satu tugas hakim adalah menyelidiki apakah suatu hubungan hukum yang menjadi dasar gugatan telah benar-benar ada atau tidak. Adanya hubungan hukum inilah yang harus terbukti apabila penggugat menginginkan kemenangan dalam suatu perkara. Apabila penggugat tidak berhasil untuk membuktikan dalil-dalilnya yang menjadi dasar gugatannya, maka gugatannya akan dikalahkan, dan apabila mampu membuktikan gugatannya maka gugatannya pasti akan dimenangkan.

Tidak semua dalil yang menjadi dasar gugatan harus dibuktikan kebenarannya, sebab dalil-dalil yang tidak disangkal, apabila diakui sepenuhnya oleh pihak lawan, tidak perlu dibuktikan lagi. Dalam hal pembuktian tidak selalu pihak penggugat saja yang harus membuktikan dalilnya. Majelis Hakim yang memeriksa perkara itu yang akan menentukan siapa diantara pihak-pihak yang berperkara itu yang akan diwajibkan untuk mengajukan alat bukti.

Pembuktian itu hanya diperlukan apabila timbul suatu sanggahan, jika tidak ada sanggahan maka tidak perlu adanya pembuktian. Selain untuk hal-hal yang telah diakui atau setidak-tidaknya tidak disangkal, terdapat satu hal lagi yang tidak harus dibuktikan, yaitu hal atau keadaan yang telah diketahui oleh umum, dalam hal ini menurut hukum acara perdata disebut dengan "fakta notaris". Fakta notaris merupakan keadaan yang langsung diketahui sendiri oleh majelis hakim. ${ }^{5}$

Dalam sengketa yang berlangsung di persidangan pengadilan, masing-masing pihak dibebani untuk menunjukkan dalil-dalil (posita) yang saling berlawanan, majelis hakim harus memeriksa dan menetapkan dalil-dalil manakah yang benar dan yang tidak benar berdasarkan duduk perkaranya yang ditetapkan sebagai yang sebenarnya. Keyakinan hakim itu dibangun berdasarkan pada sesuatu yang oleh undang-undang dinamakan alat bukti. Dengan alat bukti, masing-masing pihak berusaha membuktikan dalilnya atau pendiriannya yang dikemukakan di hadapan Majelis Hakim dalam persidangan.

\footnotetext{
${ }^{4}$ Hartono, Penyidikan \& Penegakan Hukum Pidana Melalui Pendekatan Hukum Progresif (Jakarta: Sinar Grafika, 2010), 59.

${ }^{5}$ Ahmad Mujahidin, Pembaharuan Hukum Acara Peradilan Agama, 174.
} 
Dalam hukum acara perdata, untuk memenangkan di antara pihak yang berperkara, tidak perlu adanya keyakinan hakim, yang penting adalah alat-alat bukti yang sah yang berdasarkan alat-alat bukti tersebut majelis hakim akan mengambil keputusan siapa yang menang dan siapa yang kalah. Dengan kata lain, dalam hukum acara perdata cukup dengan kebenaran formil saja.

Merupakan suatu asas bahwa barang siapa yang mendalilkan sesuatu dia harus membuktikannya. Sepintas, asas tersebut kelihatannya sangat mudah, meski sesungguhnya dalam praktik merupakan hal yang sangat sukar untuk menentukan secara tepat, siapa yang harus dibebani kewajiban untuk membuktikan sesuatu, sekalipun yang perlu dikemukakan sebagai patokan bahwa hendaknya tidak hanya satu pihak saja yang diwajibkan memberikan bukti, namun juga harus dilihat secara kasus per kasus (masalah per masalah). ${ }^{6}$

Menurut Pasal 184 KUHAP, alat-alat bukti ialah:

1. Keterangan saksi;

2. Keterangan ahli;

3. Surat;

4. Petunjuk;

5. Keterangan terdakwa. ${ }^{7}$

Alat bukti yang dapat dipergunakan dalam persidangan Pengadilan Agama adalah terdiri atas lima macam, yaitu sebagai berikut:

1. Alat bukti surat/alat bukti akta.

2. Alat bukti saksi.

3. Alat bukti persangkaan.

4. Alat bukti pengakuan.

5. Alat bukti sumpah.

Dalam praktik, terdapat satu alat bukti lagi yang sering dipergunakan, yaitu pengetahuan hakim. Di sini, yang dimaksud dengan pengetahuan hakim adalah keadaan yang diketahui langsung oleh Majelis Hakim dalam persidangan, misalnya, Majelis Hakim melihat sendiri pada waktu melakukan pemeriksaan setempat.

Hal-hal atau keadaan yang diketahui Majelis Hakim atau Anggota Majelis Hakim di luar sidang adalah bukan merupakan pengetahuan

\footnotetext{
${ }^{6}$ Ahmad Mujahidin, Pembaharuan Hukum Acara Peradilan Agama, 174

${ }^{7}$ Andi Hamzah, Hukum Acara Pidana Indonesia Edisi Kedua, (Jakarta: Sinar Grafika, 2009), 259
} 
hakim, melainkan pengetahuan bapak atau ibu hakim sendiri atau pribadi, yang secara kebetulan mengetahui hal tersebut. ${ }^{8}$

Bukti, secara global merupakan sebutan segala sesuatu yang menjelaskan dan mengungkap kebenaran. Terutama dua orang saksi, atau empat orang saksi, atau satu orang saksi yang tidak terhalang haknya untuk menjadi saksi atas nama dua orang saksi.

Al-Qur'an menyebut pembuktian tidak hanya semata-mata dalam arti dua orang saksi. Akan tetapi, juga dalam arti keterangan, dalil, dan alasan, baik secara sendiri-sendiri maupun komulasi.

Rasulullah saw. menjelaskan masalah pembebanan pembuktian ini sebagai berikut:

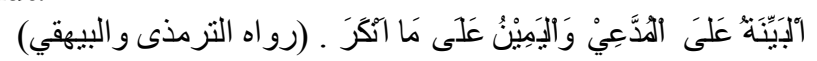

"Bukti itu atas yang menggugat, sedang sumpah atas yang tergugat (atas orang yang menolak gugatan)". (HR. Tirmidzi dan Baihaqi). ${ }^{9}$

Adagium tersebut dimaksudkan, bahwa untuk mendapatkan hukum yang sesuai dengan petitum gugatannya, seorang penggugat harus mengemukakan bukti-bukti yang membenarkan dalil-dalil gugatannya, dan dua orang saksi adalah termasuk alat bukti. ${ }^{10}$

Seorang terdakwa wajib menghadirkan beberapa orang saksi dengan minimal dua orang saksi dalam melakukan pemeriksaan di persidangan. Sebagaimana yang telah dijelaskan dalam Firman Allah swt:

"Dan persaksikanlah dengan dua orang saksi dari orang-orang lelaki (di antaramu). Jika tak ada dua orang lelaki, maka (boleh) seorang lelaki dan dua orang perempuan dari saksi-saksi yang kamu ridhai, supaya jika seorang lupa maka seorang lagi mengingatkannya". (QS. Al-Baqarah : 282) $)^{11}$

Secara yuridis normatif, setiap permintaan tersangka untuk menghadirkan saksi yang menguntungkan baginya harus dipenuhi oleh penyidik dan penyidik wajib memeriksa saksi yang bersangkutan. Namun demikian bahwa dalam penanganan suatu perkara pidana, KUHAP kita menganut asas cepat, sederhana dan biaya ringan. Oleh karena itu sebelum memanggil dan memeriksa saksi yang diminta oleh tersangka tersebut, kiranya tepat bila terlebih dahulu penyidik meneliti

\footnotetext{
${ }^{8}$ Ahmad Mujahidin, Pembaharuan Hukum Acara Peradilan Agama, 175.

9 Tengku Muhammad Hasbi Ash Shiddieqy, Peradilan dan Hukum Acara Islam (Semarang: PT. Pustaka Rizki Putra, 1997), 132.

${ }^{10}$ Ibnu Qayyim Al-jauziyah, Hukum Acara Peradilan Islam (Yogyakarta: Pustaka Pelajar, 2006), 15.

${ }^{11}$ Depag RI, Al-Qur'an dan Terjemahannya (Jakarta: CV. Diponegoro, 2000), 37.
} 
sejauh mana relevansi dan urgensi, pemeriksaan saksi a de charge tersebut.

Apabila ternyata permintaan tersangka tersebut tidak beralasan, keterangan saksi yang diminta tidak ada relevansi dan urgensinya, bahkan diperoleh petunjuk bahwa permintaan tersangka tersebut hanya dilandasi oleh motivasi untuk mengulur-ulur waktu dengan harapan pemeriksaan tidak dapat diselesaikan selama masa penahanan dan tersangka mengharapkan ia dibebaskan dari tahanan demi hukum, sebaiknya permintaan tersangka demikian tidak perlu dilayani oleh penyidik. $^{12}$

Dalam tulisan ini persoalan yang dituangkan penulis adalah persoalan tentang pembuktian perkara illegal fishing yang ada dalam putusan Mahkamah Agung No. $84 \mathrm{PK} / \mathrm{Pid} / 2005$. Bahwa seorang warga negara asing yang bernama Jai Hadsadee yaitu orang Thailand telah melakukan usaha perikanan dibidang penangkapan ikan tanpa ijin di Perairan Laut Jawa. Bahwa pertimbangan hukum Judex facti Pengadilan Tinggi Surabaya dan Mahkamah Agung Republik Indonesia (MARI) telah melakukan kekhilafan dan kekeliruan, yaitu Pengadilan Negeri Gresik, Pengadilan Tinggi Surabaya dan MARI sama sekali tidak mempertimbangkan hasil pembuktian yang terungkap di persidangan tingkat pertama (Pengadilan Negeri Gresik), termasuk Jaksa Penuntut Umum sama sekali tidak dapat/tidak sanggup membuktikan siapa pemilik kapal sesungguhnya sesuai surat-surat bukti. Karena Jaksa Penuntut Umum tidak menghadirkan pemilik Kapal MV Siriwanphen (Phaiboon) di persidangan untuk dijadikan sebagai saksi, guna menerangkan benar tidaknya Phaiboon adalah pemilik kapal dan juga apakah benar/tidaknya Phaiboon yang menyuruh dan atau memerintahkan Pemohon Peninjau Kembali untuk memasuki wilayah perairan Indonesia (Laut Jawa) untuk mentransfer, pemuatan, dan pembelian ikan.

Kalaupun benar menurut hukum, Phaiboon adalah pemilik kapal MV Siriwanphen dan menyuruh/memerintahkan Pemohon Peninjau Kembali melakukan pelayaran memasuki wilayah perairan Indonesia, maka tanggung jawab pidana bukan saja pada Pemohon Peninjau

\footnotetext{
12 Hamrat Hamid, Harun M. Husein, Pembahasan Permasalahan KUHAP Bidang Penyidikan (Jakarta: Sinar Grafika, 1992), 52.
} 
Kembali, akan tetapi Phaiboon selaku pemilik kapal juga harus ikut turut serta melakukan kejahatan perikanan.

Oleh karena Jaksa Penuntut Umum tidak sanggup menghadirkan pemilik kapal (Phaiboon) di persidangan sebagaimana tersebut di atas, maka Pengadilan Tinggi Surabaya dan MARI melakukan kekhilafan dan kekeliruan atau error facti yang menyatakan 1 (satu) buah kapal MV Siriwanphen bersama 1 (satu) bundel dokumen kapal dirampas untuk negara. ${ }^{13}$

\section{Pengertian Pembuktian}

Pembuktian menurut istilah bahasa Arab berasal dari kata "albayyinah" yang artinya suatu yang menjelaskan. ${ }^{14}$ Secara etimologi berarti keterangan, yaitu segala sesuatu yang dapat menjelaskan hak (benar). Dalam istilah teknis, berarti alat-alat bukti dalam sidang pengadilan. Ulama fiqh membahas alat bukti dalam persoalan pengadilan dengan segala perangkatnya. Dalam fiqh, alat bukti disebut juga turuq al-isbât. ${ }^{15}$

Al-bayyinah didefinisikan oleh ulama fiqh sesuai dengan pengertian etimologisnya. Jumhur ulama fiqh mengartikan al-bayyinah secara sempit, yaitu sama dengan kesaksian. Namun, menurut Ibnu alQayyim al-Jauziyah, tokoh fiqh Mazhab Hanbali, al-bayyinah mengandung pengertiang yang lebih luas dari definisi jumhur ulama tersebut. Menurutnya, kesaksian hanya salah satu jenis dari al-bayyinah yang dapat digunakan untuk mendukung dakwaan seseorang. Albayyinah didefinisikan oleh Ibnu al-Qayyim al-Jauziyah sebagai segala sesesuatu yang dapat digunakan intuk menjelaskan yang hak (benar) di depan majelis hakim, baik berupa keterangan, saksi, dan berbagai indikasi yang dapat dijadikan pedoman oleh majelis hakim untuk mengembalikan hak kepada pemiliknya. ${ }^{16}$

Secara terminologis, pembuktian berarti memberikan keterangan dengan dalil hingga meyakinkan. Beberapa pakar hukum Indonesia memberikan berbagai macam pengertian mengenai pembuktian. Prof. Dr. Supomo misalnya, dalam bukunya Hukum Acara Perdata

\footnotetext{
${ }^{13}$ Salinan Putusan Mahkamah Agung Nomor 84 PK/Pid/2005

${ }^{14}$ Sulaikhan Lubis, Hukum Acara Perdata Peradilan Agama di Indonesia (Jakarta: Kencana Prenada Media Group, 2005), 135.

${ }^{15}$ Abdul Aziz Dahlan, Ensiklopedi Hukum Islam (Jakarta: Ichtiar Baru Van Hoeve, 1996), 207.

${ }^{16} \mathrm{lbid}$.
} 
Pengadilan Negeri menerangkan bahwa pembuktian mempunyai arti luas dan arti terbatas. Dalam arti luas, pembuktian berarti memperkuat kesimpulan dengan syarat-syarat bukti yang sah, sedangkan dalam arti terbatas pembuktian itu hanya diperlukan apabila yang dikemukakan oleh penggugat itu dibantah oleh tergugat. ${ }^{17}$

Dalam hukum Islam, keyakinan hakim memiliki beberapa tingkatan. Tingkatan keyakinan hakim tersebut adalah sebagai berikut:

1. Yaqîn: meyakinkan, yaitu si hakim benar-benar yakin (terbukti $100 \%)$.

2. Zhan: sangkaan yang kuat, yaitu lebih condong untuk membenarkan adanya pembuktian (terbukti $75-99 \%$ ). ${ }^{18}$ Zhan ini tidak dapat dipergunakan untuk menetapkan apa yang menjadi tantangan bagi apa yang telah diyakini itu. Lebih-lebih lagi kalau zhan itu nyata pula salahnya. Di dalam kitab al-Ashbâh wan Nadhîr, karangan As-Suyuti dan Ibnu Nujaim ada suatu kaidah, yaitu:

"Tidak sah menjadi pegangan zhan yang nyata salah."

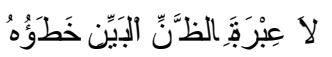

Hanya saja sebagai yang sudah dikatakan, bahwa zhan itu kalau masuk ke dalam golongan zhan yang kuat, maka dia dapat mengganti yakin, apabila yakin itu sukar diperoleh. ${ }^{20}$

3. Shubhat: ragu-ragu (terbukti $50 \%$ ).

4. Wahm: sangsi, lebih banyak tidak adanya pembuktian dari pada adanya (terbukti $<50 \%$ ), maka pembuktiannya lemah.

Suatu pembuktian diharapkan dapat memberikan keyakinan hakim pada tingkat yang meyakinkan (terbukti 100\%) dan dihindarkan pemberian putusan apabila terdapat kondisi shubhat atau yang lebih rendah. Hal ini dikarenakan dalam pengambilan keputusan berdasar kondisi shubhat ini dapat memungkinkan adanya penyelewengan. Nabi Muhammad SAW., lebih cenderung mengharamkan atau menganjurkan untuk meninggalkan perkara shubhat. ${ }^{21}$

\footnotetext{
${ }^{17}$ Sulaikhan Lubis, Hukum Acara Perdata Peradilan Agama di Indonesia, 136.

${ }^{18}$ Ibid, 136

${ }^{19}$ Tengku Muhammad Hasbi Ash Shiddieqy, Peradilan dan Hukum Acara Islam (Semarang: PT.

Pustaka Rizki Putra, 1997), 130

${ }^{20} \mathrm{lbid}$

${ }^{21}$ Sulaikin Lubis, Hukum Acara Perdata Peradilan Agama di Indonesia, 136
} 
Menurut Ibnu Qayyim al-Jauziyah, dalam al-Qur'an maupun sunah Rasulullah saw tidak ada penjelasan yang menyatakan bahwa albayyinah itu khusus untuk kesaksian. Al-Qur'an dan sunnah hanya menjelaskan bahwa al-bayyinah itu adalah dalil, hujjah, dan keterangan yang dapat dijadikan alasan.

Menurut ulama fiqh, dalam suatu persengketaan di depan majelis hakim pihak penggugat harus mengemukakan alat bukti yang dapat mendukung gugatannya atau hakim berkewajiban untuk meminta alat bukti dari penggugat, sehingga hakim dapat meneliti persoalan yang dipersengketakan dan menetapkan hukum secara adil sesuai dengan alat bukti yang meyakinkan. Apabila suatu gugatan tidak dibarengi dengan alat bukti yang meuakinkan, maka gugatan tidak dapat diterima. Dengan demikian, dalam memutus suatu perkara, hakim terikat dengan alat bukti yang diajukan penggugat. Apabila alat bukti yang diajukan penggugat meyakinkan dan pihak tergugat tidak bisa membantah atau melemahkan alat bukti tersebut, maka hakim akan memutus perkara sesuai dengan alat bukti yang ada. ${ }^{22}$

Perbedaan pendapat timbul di antara ulama fiqh dalam persoalan jika alat bukti yang diajukan ternyata palsu, sementara kepalsuannya tidak bisa dibuktikan dalam sidang. Jumhur ulama fiqh, termasuk Imam Abu Yusuf dan Muhammad bin Hasan asy-Syaibani, keduanya tokoh fiqh terkemuka Mazhab Hanafi, berpendapat bahwa hakim hanya bertugas memutus perkara sesuai dengan alat bukti yang diajukan kepadanya. Apabila alat bukti itu palsu, maka hakim tidak bertanggungjawab atas pemalsuaannya selama tidak dapat dibuktikan di depan majelis hakim, dan jika memang alat bukti yang diajukan penggugat itu palsu, maka penggugat bertanggungjawab secara batin (agama) kepada Allah swt. Hal ini sejalan dengan kaidah fiqh yang menyatakan bahwa "Kita hanya menghukum sesuai dengan yang zhâhir (keterangan yang ada), sedangkan persoalan yang tersembunyi menjadi urusan Allah." Dalam hubungan ini, jika alat bukti yang diajukan itu palsu dan kepalsuannya tidak bisa dibuktikan di depan majelis hakim, lalu hakim memutus perkaranya, maka yang memenangkan perkara bertanggungjawab kepada Allah swt. Jumhur ulama fiqh menyatakan

22 lbid. 
bahwa hakim tidak bertanggungjawab atas segala urusan yang tersembunyi. ${ }^{23}$

Lain halnya dengan pendapat Imam Abu Hanifah. Menurutnya, sekalipun alat bukti yang digunakan ternyata palsu, hukuman yang diputuskan oleh hakim berlaku secara lahir dan batin. Akan tetapi, pihak penggugat yang dimenangkan tetap bertanggungjawab kepada Allah swt atas pemalsuan alat bukti tersebut. Walaupun demikian, menurutnya, suatu putusan hakim baru bisa berlaku secara lahir dan batin apabila memenuhi dua syarat berikut:

1. Hakim tidak boleh mengetahui kepalsuan alat bukti,

2. Objek yang dipersengketakan itu bisa diserahkan secara lahir dan batin kepada pihak penggugat. ${ }^{24}$

\section{Macam-Macam Alat Bukti}

Alat-alat bukti (hujjah), ialah sesuatu yang membenarkan gugatan.

Para fuqaha berpendapat, bahwa hujjah (bukti-bukti) itu ada 7 macam: ${ }^{25}$

1. Iqrâr (pengakuan),

2. Shahâdah (kesaksian),

3. Yamîn (sumpah),

4. Nukûl (menolak sumpah),

5. Qasâmah (sumpah),

6. Keyakinan hakim,

7. Bukti-bukti lainnya yang dapat dipergunakan.

Menurut Samir 'Aliyah, alat-alat bukti itu ada enam dengan urutan sebagai berikut: ${ }^{26}$

1. Pengakuan,

2. Saksi,

3. Sumpah,

4. Qarînah,

5. Bukti berdasarkan indikasi-indikasi yang tampak,

6. Pengetahuan hakim.

Menurut 'Abdul Karim Zaidan, alat-alat bukti itu ada sembilan dengan urutan sebagai berikut:

\footnotetext{
${ }^{23} \mathrm{Ibid}$.

${ }^{24}$ Ibid.

${ }^{25}$ Tengku Muhammad Hasbi Ash Shiddieqy, Peradilan dan Hukum Acara Islam, 136.

${ }^{26}$ Anshoruddin, Hukum Pembuktian Menurut Hukum Acara Islam dan Hukum Positif(Yogyakarta: Pustaka Pelajar, 2004), 57.
} 
1. Pengakuan

2. Saksi

3. Sumpah

4. Penolakan sumpah

5. Pengetahuan hakim

6. Qarînah

7. Qasâmah

8. Qifâyah

9. Qur'ah

Menurut Ibnu Qayyim al-Jauziyah, alat-alat bukti itu ada dua puluh enam dengan urutan sebagai berikut: ${ }^{27}$

1. Fakta yang bicara atas dirinya sendiri yang tidak memerlukan sumpah.

2. Pengingkaran penggugat atas jawaban tergugat.

3. Fakta yang berbicara atas dirinya sendiri disertai sumpah pemegangnya.

4. Pembuktian dengan penolakan sumpah berlaka.

5. Penolakan sumpah dan sumpah yang dikembalikan.

6. Saksi satu orang laki-laki tanpa sumpah penggugat.

7. Saksi satu orang laki-laki dengan sumpah penggugat.

8. Keterangan saksi satu orang laki-laki dan dua orang perempuan.

9. Keterangan saksi satu orang laki-laki dan penolakan tergugat untuk bersumpah.

10.Keterangan saksi/dua orang perempuan dan sumpah penggugat.

11.Saksi dua orang perempuan tanpa sumpah.

12.Saksi tiga orang laki-laki.

13.Saksi empat orang laki-laki.

14.Kesaksian budak.

15.Kesaksian anak-anak dibawah umur (sudah mumayyiz).

16.Kesaksian orang yang fasiq.

17.Kesaksian orang non Islam.

18.Bukti pengakuan.

19.Pengetahuan hakim.

20.Berdasarkan berita mutawâtir.

21. Berdasarkan berita tersebar (khabar istifâdah).

22.Berdasarkan berita orang perorang.

${ }^{27}$ Ibid, 58 


\section{Bukti tulisan.}

24.Berdasarkan indikasi-indikasi yang nampak.

25.Berdasarkan hasil undian.

26.Berdasarkan hasil penelusuran jejak.

Ada berbagai alat bukti yang dapat diajukan ke dalam persidangan di pengadilan berdasarkan Hukum Islam. Alat-alat bukti tersebut antara lain: ${ }^{28}$

1. Iqrâr (pengakuan)

2. Shahâdah (saksi)

3. Yamin (sumpah)

4. Riddah (murtad)

5. Maktûbah (bukti tertulis)

6. Tabayyun (pemeriksaan koneksitas)

7. Alat bukti untuk bidang pidana.

Dalam tulisan ini hanya akan dibahas alat-alat bukti yang ada dalam kaitan dengan sistem peradilan agama di Indonesia. Di antaranya adalah sebagai berikut:

a. Iqrâr (pengakuan)

Iqrâr yaitu suatu pernyataan dari penggugat atau tergugat atau pihak-pihak lainnya mengenai ada tidaknya sesuatu. Ikrar adalah pernyataan seseorang tentang dirinta sendiri yang bersifat sepihak dan tidak memerlukan persetujuan pihak lain. Ikrar atau pengakuan dapat diberikan di muka Hakim di persidangan atau di luar persidangan.

Syarat-syarat pelaku ikrar:

1. Baligh : dewasa,

2. Aqil : berakal/waras, tidak gila,

3. Rasyid : punya kecakapan bertindak.

Jenis ikrar:

1. Lisan,

2. Isyarat, kecuali dalam perkara zina.

3. Tertulis

b. Shahâdah (saksi)

Saksi ialah orang yang memberikan keterangan di muka sidang, dengan memenuhi syarat-syarat tertentu, tentang suatu

\footnotetext{
${ }^{28}$ Sulaikin Lubis, Hukum Acara Perdata Peradilan Agama di Indonesia, 139
} 
peristiwa atau keadaan yang ia lihat, dengar, dan ia alami sendiri, sebagai bukti terjadinya peristiwa atau keadaan tertentu. ${ }^{29}$

Pengertian persaksian, sebagaimana dikemukakan oleh Wahbah Zuhaili adalah sebagai berikut:

"Persaksian adalah suatu pemberitahuan (pernyataan) yang benar untuk membuktikan suatu kebenaran dengan lafadz syahadat di depan pengadilan". ${ }^{30}$

Syarat sah saksi:
a. Muslim;
b. Sehat akal;
c. Baligh;
d. Tidak fasik.

As-Sayid Sabiq dalam kitabnya Fiqh al-Sunnah merinci tujuh hal yang harus dipenuhi sebagai saksi, antara lain:

a. Islam,

b. Adil (bahwa kebaikan mereka harus mengalahkan keburukannya serta tidak pendusta),

c. Baligh,

d. Berakal (tidak gila atau mabuk),

e. Berbicara (tidak bisu),

f. Hafal dan cermat, dan

g. Bersih dari tuduhan.

Orang-orang yang ditolak untuk menjadi saksi adalah di antaranya sebagai berikut:

1. Yang bermusuhan dengan pihak yang berperkara.

2. Mahram,

3. Yang berkepentingan atas perkara itu,

4. Sakit jiwa,

5. Fasik; yaitu orang yang suka menyembunyikan yang benar dan menampakkan yang salah,

6. Safîh; yang lemah akal atau di bawah pengampuan. ${ }^{31}$

c. Yamîn (sumpah)

Sumpah ialah suatu pernyataan yang khidmad yang diberikan atau diucapkan pada waktu memberi janji atau keterangan dengan mengingat sifat Maha Kuasa Tuhan dan percaya bahwa siapa yang

${ }^{29}$ lbid.

${ }^{30}$ Ahmad Wardi Muslih, Hukum Pidana Islam (Jakarta: Sinar Grafika Offset), 231 .

${ }^{31}$ Sulaikin Lubis, Hukum Acara Perdata Peradilan Agama di Indonesia, 140. 
memberi keterangan atau janji yang tidak benar akan dihukum olehNya. Sumpah menurut hukum Islam disebut al-yamîn atau al-hilf tetapi kata al-yamîn lebih umum dipakai. Sedangkan sumpah di lapangan pidana disebut qasâmah. ${ }^{32}$

Alat bukti sumpah tidak bisa berdiri sendiri. Artinya, hakim tidak bisa memutus hanya semata-mata mendasarkan kepada sumpah tanpa disertai oleh alat bukti lainnya. Sumpah hanyalah merupakan salah satu alat bukti yang dapat diandalkan untuk pengambilan putusan terakhir.

Fungsi sumpah dan nilai kekuatan pembuktiannya:

1. Memberikan rasa takut, emosional sugesti, kepada terdakwa akan akibat sumpah palsu, sehingga akan mendorongnya memberi pengakuan secara jujur.

2. Dengan menolak bersumpah, terdakwa/tergugat menjadi pihak yang dikalahkan, karena nilai kekuatan pembuktian penolakannya itu menempati kedudukan pengakuan. ${ }^{33}$

d. Maktûbah (Bukti-bukti tertulis)

Bukti-bukti tertulis yang dimaksud di sini terdiri atas dua hal, yaitu akta dan surat keterangan.

1. Akta diperlukan sebagai alat bukti, misalnya dalam hal membuktikan kompetensi absolut suatu perkara yang dapat diputus oleh hakim pengadilan agama.

2. Surat keterangan digunakan untuk pembuktian kompetensi relatif bagi pengadilan agama yang memutus perkara tersebut. Surat keterangan yang dimaksud misalnya adalah surat keterangan domisili pihak-pihak yang bersengketa. ${ }^{34}$

Ada beberapa fungsi surat atau akta ditinjau dari segi hukum, yaitu sebagai berikut:

1. Sebagai syarat menyatakan perbuatan hukum. Dalam beberapa peristiwa atau perbuatan hukum, akta ditetapkan sebagai syarat pokok (formalitas causa), tanpa akta dianggap perbuatan hukum yang dilakukan tidak memenuhi syarat formil. Sebagai contoh, perbuatan hukum memanggil penggugat atau tergugat untuk

\footnotetext{
${ }^{32} \mathrm{lbid}$.

${ }^{33}$ Ibnu Qayyim al-Jauziyah, Hukum Acara Peradilan Islam (Yogyakarta: Pustaka Pelajar, 2006), 201.

${ }^{34}$ Sulaikin Lubis, Hukum Acara Perdata Peradilan Agama di Indonesia, 142.
} 
menghadiri sidang, hal tersebut harus dilakukan dengan akta (eksploite), sebab jika tidak demikian dinyatakan tidak sah.

2. Sebagai alat bukti. Pada umumnya, pembuatan akta tidak lain dimaksudkan sebagai alat bukti, sekaligus juga melekat sebagai syarat menyatakan perbuatan dan sekaligus dimaksudkan sebagai fungsi alat bukti, dengan demikian suatu akta bisa berfungsi ganda.

3. Sebagai alat bukti satu-satunya. Dalam hal ini, surat (akta) berfungsi sebagai "probationis causa", sebab tanpa surat (akta) maka tidak dapat dibuktikan dengan alat bukti lain. ${ }^{35}$

e. Tabâyun (limpahan pemeriksaan)

Tabâyun adalah upaya perolehan kejelasan yang dilakukan oleh pemeriksaan majelis pengadilan yang lain dari pada majelis pengadilan yang sudah memeriksa. ${ }^{36}$

Di samping alat-alat bukti tersebut di atas, Ibnu Qayyim mengemukakan alat bukti lain, antara lain sebagai berikut: ${ }^{37}$

1. Al-yad al-mujarrad (penguasaan semata-mata terhadap sesuatu), yaitu bukti yang tidak memerlukan sumpah, seperti anak-anak atau orang yang berada di bawah pengampuan, yang memiliki harta peninggalan ayahnya. Dengan dasar penguasaan kasus seperti ini telah cukup sebagai alat bukti sehingga tidak diperlukan sumpah. ${ }^{38}$

2. Al-inkâr al-mujarrad (pengingkaran semata-mata terhadap suatu gugatan).

Abdurrahman Ibrahim Abdul Aziz al-Humaidi, ahli fiqh kontemporer dari Arab Saudi, menyatakan bahwa untuk zaman kontemporer alat bukti lain yang dapat digunakan adalah alat bukti tulisan yang dianggap sah oleh lembaga pengadilan. Alasannya didasarkan pada firman Allah SWT. yang berbunyi: "Hai orang-orang yang beriman, apabila kamu bermuamalah tidak secara tunai untuk waktu yang ditentukan, hendaklah kamu menuliskannya..." (QS. Al-Baqarah(2): 282) ${ }^{39}$

\footnotetext{
${ }^{35}$ Ahmad Mujahidin, Pembaharuan Hukum Acara Peradilan Agama (Bogor: Ghalia Indonesia, 2012), 176.

${ }^{36}$ Sulaikin Lubis, Hukum Acara Perdata Peradilan Agama di Indonesia, 143.

${ }^{37}$ Abdul Aziz Dahlan, Ensiklopedi Hukum Islam, 208.

${ }^{38}$ Basiq Djalil, Peradilan Islam (Jakarta: Amzah, 2012), 34.

${ }^{39}$ Depag RI, Al-Qur'an dan Terjemahannya (Jakarta: CV. Diponegoro, 2000), 37.
} 
3. Bukti penguasaan atas sesuatu dan sumpah atasnya, seperti bila ada seseorang yang dituduh bahwa yang dimilikinya adalah bukan miliknya, kemudian pemilik hak itu menyangkal atas tuduhan tersebut, lalu ia diminta bersumpah maka pemilik hak itu menjadi miliknya, dan jika tidak mau sumpah maka dicabutlah hak itu dari kekuasaannya.

4. Penolakan, yang dimaksud penolakan ini adalah menolaknya mud'â alaih (tertuduh/tergugat) untuk bersumpah sebagaimana diminta oleh mudda'î (penuntut umum/penggugat). Karena menolak sumpah dianggap sebagai penguat suatu tuduhan/gugatan maka kekuatan bukti ini dapat disamakan dengan pengakuan.

5. Menolak sumpah dan mengembalikan sumpah kepada penggugat. Ada suatu hadis yang diriwayatkan oleh Daruquthni dari Nafi' Ibnu Umar bahwa Nabi saw pernah meminta kepada penggugat untuk bersumpah. Hadis tersebut berbunyi sebagai berikut:

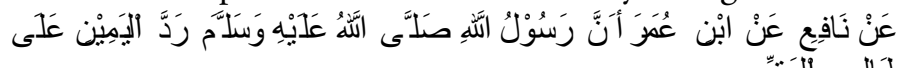

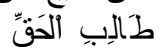

"Dari Nafi' dari Ibnu Umar, bahwa sesungguhnya Rasulullah saw pernah mengembalikan sumpah kepada penggugat hak." (HR. ad-Daruqutni) $)^{40}$

\section{Dasar Hukum Pembuktian}

Dalam hukum Islam, terdapat banyak ayat al-Qur'an sebagai landasan berpijak tentang pembuktian. Di antaranya adalah sebagai berikut: ${ }^{41}$

"Dan persaksikanlah dengan dua orang saksi dari orang-orang lelaki (di antaramu). Jika tak ada dua orang lelaki, maka (boleh) seorang lelaki dan dua orang perempuan dari saksi-saksi yang kamu ridhai, supaya jika seorang lupa maka seorang lagi mengingatkannya”. (QS. Al-Baqarah : 282) ${ }^{42}$

Dan firman Allah swt:

"Kemudian apabila kamu menyerahkan harta kepada mereka, maka hendaklah kamu adakan saksi-saksi (tentang penyerahan

\footnotetext{
${ }^{40}$ Basiq Djalil, Peradilan Islam (Jakarta: Amzah, 2012), 34-36.

${ }^{41}$ Sulaikin Lubis, Hukum Acara Perdata Peradilan Agama di Indonesia, 138.

${ }^{42}$ Depag RI, Al-Qur'an dan Terjemahannya, 37.
} 
itu) bagi mereka. Dan cukuplah Allah sebagai pengawas (atas persaksian itu)”. (QS. An-Nisa' : 6) ${ }^{43}$

Firman Allah swt:

"Dan persaksikanlah dengan dua orang saksi yang adil diantara kamu dan hendaklah kamu tegakkan kesaksian itu karena Allah". (QS. Ath-Thalaq: 2) ${ }^{44}$

\section{Macam-Macam Pembuktian}

Bukti res upsa loquiter adalah fakta berbicara atas dirinya sendiri.

Dan bukti res upsa loquiter ada tiga macam, yaitu:

1. Barang hasil kejahatan dan penipuan.

Jika suatu barang berada dalam kekuasaan seseorang lalu indikasi-indikasi yang nyata menunujukkan barang tersebut hasil kejahatan atau penipuannya, maka pengakuan orang yang menguasainya sebagai barang miliknya tidak dapat diterima.

2. Barang itu diketahui milik sah orang yang menguasainya.

Jika diketahui sesuatu barang yang berada dalam kekuasaan seseorang sebagai miliknya yang sah, maka gugatan orang terhadapnya tidak diterima.

Jika kita mempertimbangkan lamanya waktu kedaluwarsa, maka Ibnu Qayyim, Ibnu Wahab, Ibnu Abdul Hakim, dan Ashbagh, menentukan bahwa lamanya waktu kedaluwarsa itu sepuluh tahun. Kemungkinan mereka beralasan hadits yang disebutkan dari Said bin al-Musayyab, dan Zaid bin Aslam, bahwa Rasulullah saw bersabda:

"Barang siapa menguasai sesuatu barang selama sepuluh tahun, maka barang itu menjadi miliknya." 45

3. Bukti res upsa loquiter yang mengandung dua kemungkinan.

Bukti res upsa loquiter ada yang mengandung dua kemungkinan, yaitu kemungkinan ia milik sah pihak yang menguasainya, dan kemungkinan penguasaannya itu dilakukan secara melawan hukum. Dalam hal yang demikian, maka gugatan dapat didengar berdasarkan bukti-bukti yang diajukan oleh penggugat. Dan jika tidak ada bukti lawan yang lebih kuat, maka barang itu ditetapkan milik penggugat, karena syari'at tidak mengubah barang

${ }^{43} \mathrm{lbid}, 62$.

${ }^{44}$ Ahmad Wardi Muslih, Hukum Pidana Islam (Jakarta: Sinar Grafika Offset), 231.

${ }^{45}$ Ibnu Qayyim Al-Jauziyah, Hukum Acara Peradilan Islam, 206. 
yang berada dalam kekuasaan seseorang yang diakui oleh adat dan oleh rasa hukum masyarakat setempat dinyatakansebagai miliknya, untuk dinyatakan sebagai miliknya yang tidak sah. ${ }^{46}$

Muncullah suatu sistem yang bukan berdasarkan keyakinan individu seorang hakim yang bebas menentukan putusan buat terdakwa. Teori ini disebut teori pembuktian berdasarkan keyakinan hakim atas alasan yang logis. Dalam teori ini terdapat suatu sistem, di mana hakim dapat memutuskan seseorang bersalah berdasarkan alatalat bukti yang berlandaskan kepada peraturan pembuktian tertentu. Jadi dalam hal ini putusan hakim tersebut dijatuhkan dengan suatu motivasi. ${ }^{47}$

Sistem atau teori pembuktian ini disebut juga pembuktian bebas karena hakim bebas untuk menyebutkan alasan-alasan keyakinannya.

Sistem ini kemudian terpecah menjadi dua jurusan, antara lain:

1. Sistem pembuktian berdasarkan keyakinan hakim atas alasan yang logis;

2. Sistem pembuktian yang logis berdasarkan Undang-Undang secara negatif.

Kedua jurusan tersebut jelas dapat disimpulkan bahwa kekuasaan hakim telah dibatasi dengan suatu ketentuan tidak bebas seperti dalam sistem sebelumnya, sehingga tidak memberi kesempatan kepada terdakwa untuk membela hak asasinya sebagai tersangka. Di mana batasan-batasan tersebut dapat dibedakan, antara lain:

1. Batasan kekuasaan yang berpangkal tolak pada keyakinan yang berdasarkan alasan logis.

2. Batasan kekuasaan yang berpangkal tolak pada keyakinan yang berdasarkan kepada undang-undang. ${ }^{48}$

\section{Cara-Cara Pembuktian}

Cara-cara untuk mengetahui keadaan-keadaan yang berhubungan dengan gugatan, atau hujjah yang menguatkan gugatan, menurut Ibnu Qayyim ada 26 cara. Dalam pada itu, sebagian besar para fuqaha antara

\footnotetext{
46 Ibid.

${ }^{47}$ Hendrastanto Yudowidagdo, Kapita Selekta Hukum Acara Pidana di Indonesia (Jakarta: Melton Putra, 1987), 240.

48 Ibid.
} 
lain Ibnu Abidin membatasi dalam dua cara saja. Pertama, gugatan (dakwa). Kedua, bukti (hujjah).

Dakwa ialah tuduhan yang dapat diterima oleh hakim untuk menuntut sesuatu hak pada orang lain, atau untuk membela haknya sendiri. Si penggugat tidak dipaksa untuk meneruskan gugatannya, apabila dia tidak mau meneruskannya lagi. Akan tetapi si penggugat, dapat dipaksa menjawab untuk mengetahui benar tidaknya gugatan itu di muka pengadilan.

Apabila si penggugat telah mengemukakan gugatannya, maka perlulah si tergugat memberikan jawabannya. Apabila dia diam, maka dapat dianggap bahwa dia menolak gugatan itu. Jika si tergugat membenarkan gugatan, atau menolaknya, tetapi dapat dibuktikan kebenaran oleh si penggugat berdasarkan bukti-bukti yang sah, maka hakim pun memutuskan perkara itu. Apabila si penggugat tidak dapat memberika bukti, maka atas permintaan si penggugat hakim menyuruh si tergugat supaya bersumpah dan sesudah itu, barulah hakim memutuskan perkara secara sumpah atau dengan menolak sumpah. ${ }^{49}$

Berdasarkan sejarah Islam, tindakan yang dilakukan Rasulullah dalam menyelesaikan perkara tidak sekedar memutuskan dan menyelesaikan perkara, akan tetapi untuk menumbuhkan kesadaran imani sebagai pintu yang dapat membuka tumbuhnya kesadaran hukum dari para pihak yang berperkara. Karena itu, dalam menyelesaikan perkara, Rasulullah senantiasa melakukannya dengan pertimbangan ijtihad, bukan berdasarkan turunnya wahyu. Demikian pula putusan yang diambil, yaitu berdasarkan pada bukti-bukti otentik, dan bukan didasarkan pada hakikat masalah. Dalam kaitan ini, terdapat hadits yang berbunyi:

"Kami memutuskan perkara berdasarkan kenyataan, dan Allah sendiri yang mengendalikan batin manusia." 50

Berdasarkan hadis tersebut, maka sebenarnya yang dicari di pengadilan itu adalah kebenaran formal, bukan kebenaran materiil. Hal itu tercermin dalam satu kasus.

Dalam menyelesaikan perkara yang kasat mata, sulit dibuktikan karena tidak cukup bukti, Rasulullah banyak menyentuh kesadaran imani dan sentuhan nurani. Dengan kata lain, Rasulullah tidak hanya

\footnotetext{
${ }^{49}$ Tengku Muhammad Hasbi Ash Shiddieqy, Peradilan dan Hukum Acara Islam, 136.

${ }^{50}$ Oyo Sunaryo Mukhlas, Perkembangan Peradilan Islam (Bogor: Ghalia Indonesia, 2011), 50.
} 
berpegang teguh kepada fakta hukum yang sebenarnya tampak, tetapi juga dengan pengakuan tulus dari para pihak untuk sejujurnya menyatakan dan menyampaikan duduk perkaranya dengan benar. Dalam menghadapi perkara-perkara itu, Rasulullah saw senantiasa memutuskan perkara tersebut berdasarkan ijtihad. Sudah barang tentu putusan yang dihasilkannya pun sangat relatif bisa benar, bisa juga salah (bisa tepat, bisa juga tidak). ${ }^{51}$

\section{Pembuktian Illegal Fishing dalam UU No. 21 Tahun 1992 tentang Pelayaran}

Pembuktian masalah illegal fishing telah diatur dalam Pasal 99 ayat (2) Undang-Undang Nomor 21 Tahun 1992 tentang Pelayaran yang berbunyi sebagai berikut:

Penyidik sebagaimana dimaksud dalam ayat (1) berwenang untuk:

a. Melakukan pemeriksaan atas kebenaran laporan atau keterangan berkenaan dengan tindak pidana di bidang pelayaran;

b. Melakukan pemanggilan dan pemeriksaan terhadap saksi dan orang yang diduga melakukan tindak pidana di bidang pelayaran;

c. Melakukan penggeledahan, penyegelan dan/atau menyita alat-alat yang digunakan untuk melakukan tindak pidana di bidang pelayaran;

d. Melakukan pemeriksaan tempat yang diduga digunakan melakukan tindak pidana;

e. Meminta keterangan dan alat bukti dari orang atau sehubungan dengan tindak pidana di bidang pelayaran;

f. Membuat dan menandatangani berita acara pemeriksaan;

g. Menghentikan penyidikan apabila tidak terdapat cukup bukti tentang adanya tindak pidana di bidang pelayaran. ${ }^{52}$

\section{Kekhilafan dan Kekeliruan serta Error facti Hakim}

Pertimbangan yang mendasari putusan Pengadilan Negeri Gresik, Pengadilan Tinggi Surabaya dan putusan MARI atas keterbuktian kesalahan Pemohon Peninjauan kembali, dimana Pemohon Peninjauan Kembali selaku Nakhoda Kapal MV Siriwanphen, kapal berbendera Thailand yang digunakan untuk mengangkut atau menyimpan ikan hasil

\footnotetext{
$51 \mathrm{lbid}, 51$.

52 Undang-Undang RI No. 21 Tahun 1992 Tentang Pelayaran, 19.
} 
tangkapan di perairan wilayah Indonesia (laut Jawa) tidak memiliki dokumen izin pelayaran, Izin Usaha Perikanan dan Surat Penangkapan Ikan (SPI) sesuai Pasal 2 huruf a.b jo Pasal 10 ayat (1) jo Pasal 25 huruf a Undang-undang No. 9 tahun 1985 tentang Perikanan.

Pertimbangan hukum Judex facti Pengadilan Tinggi Surabaya dan MARI menjatuhkan pidana kepada Pemohon Peninjauan Kembali serta memerintahkan Kapal MV Siriwanphen dirampas untuk Negara, karena Pemohon Peninjauan Kembali selaku Nakhoda Kapal Siriwanphen memasuki perairan wilayah Indonesia atas suruhan dan atau perintah pemilik Kapal MV Siriwanphen yaitu Saudara Phaiboon. Dari keterangan Pemohon Peninjauan Kembali tersebut, kemudian Judex facti Pengadilan Tinggi Surabaya maupun MARI menyatakan Kapal MV Siriwanphen adalah merupakan sarana atau alat yang dipakai untuk melakukan kejahatan. Karena itu 1 (satu) unit Kapal MV Siriwanphen dan 1 (satu) bendel dokumen kapal dirampas untuk Negara.

Pertimbangan hukum yang mendasari putusan Judex facti Pengadilan Tinggi Surabaya maupun MARI hanyalah didasarkan pada keterangan Pemohon Peninjauan Kembali saja yang dijadikan sebagai bukti petunjuk, tanpa didukung oleh 2 (dua) keterangan saksi. Sedangkan kedua orang saksi yaitu : Sampumsak Neulai dan Yau Pomee termasuk bukti-bukti surat kepemilikan kapal (lihat putusan Pengadilan Negeri Gresik alinea ke-2 halaman 5 sampai alinea ke-2 halaman 6) di mana kedua saksi tersebut (ABK Kapal MV Siriwanphen) sama sekali tidak membuktikan phaiboon adalah pemilik Kapal MV Siriwanphen, selain itu Jaksa Penuntut Umum tidak menghadirkan phaiboon selaku pemilik kapal dalam persidangan.

Dengan demikian, menurut hukum dan Undang-undang setiap perbuatan hukum/suatu kejahatan yang dilakukan oleh seseorang dan atau bertindak atas nama Badan Hukum bukan saja pelaku yang bertanggung jawab atas perbuatannya akan tetapi Pimpinannya (Phaiboon) juga harus ikut bertanggung jawab di luar sidang maupun di dalam persidangan

1. Phaiboon tidak Dihadirkan sebagai Saksi di Pengadilan

Pertimbangan hukum Judex facti Pengadilan Negeri Gresik, Pengadilan Tinggi Surabaya dan MARI sama sekali tidak mempertimbangkan hasil pembuktian yang terungkap di persidangan tingkat pertama (Pengadilan Negeri Gresik), termasuk Jaksa Penuntut 
Umum sama sekali tidak dapat/tidak sanggup membuktikan siapa pemilik kapal yang sesungguhnya sesuai surat-surat bukti. Karena Jaksa Penuntut Umum tidak menghadirkan pemilik Kapal MV Siriwanphen (phaiboon) di persidangan untuk dijadikan sebagai saksi, guna menerangkan benar tidaknya phaiboon adalah pemilik Kapal dan juga apakah benar/tidaknya PHAIBOON yang menyuruh dan atau memerintahkan Pemohon Peninjauan Kembali untuk memasuki Wilayah perairan Indonesia (Laut Jawa) untuk mentransfer, pemuatan, dan pembelian ikan;

Kalaupun benar menurut hukum PHAIBOON adalah pemilik kapal MV Siriwanphen dan menyuruh/memerintahkan Pemohon Peninjauan Kembali melakukan pelayaran memasuki wilayah perairan Indonesia, maka tanggung jawab pidana bukan saja pada pemohon peninjauan Kembali, akan tetapi Phaiboon selaku pemilik Kapal juga harus ikut turut serta melakukan kejahatan perikanan (vide Pasal 55 KUHP jo Pasal 2 huruf a.b jo Pasal 10 ayat (1) jo Pasal 25 huruf a Undang-undang No. 9 tahun 1985 tentang Perikanan tersebut).

Oleh karena Jaksa Penuntut Umum tidak sanggup menghadirkan pemilik Kapal (Phaiboon) di persidangan sebagaimana tersebut diatas, maka Pengadilan Tinggi Surabaya dan MARI melakukan kekhilafan dan kekeliruan atau error facti yang menyatakan 1 (satu) buah kapal MV Siriwanphen bersama 1 (satu) bundel dokumen kapal dirampas untuk negara. ${ }^{53}$

2. Novum (Bukti Baru)

Membuktikan kekhilafan dan kekeliruan serta error facti dilakukan oleh Judex facti Pengadilan Negeri Gresik dan Pengadilan Tinggi Surabaya serta MARI terhadap penilaian bukti-bukti kepemilikan kapal MV Siriwanphen, maka Pemohon Peninjauan Kembali mengajukan sebagai bukti baru (novum) yang diterjemahkan dalam Bahasa Indonesia dan di Legalisir serta disahkan/diperiksa oleh Keduataan Indonesia di Bangkok Thailand (copy terlampir) adalah :

1. Kartu Tanda Penduduk Nyonya Wanphen Jongarnont pemilik kapal diberi tanda (PK.1) ;

2. Kartu Keluarga Nyonya Wanphen Jongarnont diberi tanda (PK.2);

${ }^{53}$ Salinan Putusan Mahkamah Agung Nomor 84 PK/Pid/2005, 1-8 
3. Sertifikat Kepemilikan kapal MV. Siriwanphen atas nama Nyonya Wanphen Jangarnont (PK.3);

4. Sertifikat Izin Pelayaran atas nama Nyonya Wanphen Jongarnont dari Negara Thailand serta jalur pelayaran diberi tanda (PK.4);

5. Sertifat pemeriksaan kapal atas nama Nyonya Wanphen Jongarnont diberi tanda (PK.5);

6. Surat Pernyataan dibawah sumpah pemilik Kapal yang sah dan Berita Acara Pengambilan sumpah, diberi tanda (PK.6). ${ }^{54}$

Bila dilihat putusan Judex facti Putusan Pengadilan Tinggi Surabaya dan MARI termasuk hasil pemeriksaan perkara tingkat pertama di Pengadilan Negeri Gresik tidak ada satupun alat bukti saksi maupun bukti surat yang diajukan Jaksa Penuntut Umum yang membuktikan atau menunjukkan Mr. Phaiboon adalah pemilik kapal MV Siriwanphen tersebut.

Pemohon Peninjauan Kembali sama sekali tidak mengetahui secara pasti siapa pemilik kapal yang sebenarnya dan hanya percaya kepada phaiboon yang mengaku sebagai pemilik kapal MV Siriwanphen.

Setelah Pemohon Peninjauan Kembali membaca dan menemukan bukti-bukti surat baru diatas yang diajukan dalam peninjauan kembali ini, barulah Pemohon Peninjauan Kembali mengetahui secara jelas bahwa tindakan Mr. Phaiboon yang mengaku selaku pemilik Kapal dan yang memerintahkan Pemohon Peninjauan Kembali untuk melakukan pelayaran diperairan wilayah Negara Indonesia adalah tidak benar dan melawan hukum, karena $\mathrm{Mr}$. Phaiboon bukan selaku pemilik kapal, maka berdasarkan hal tersebut diatas Mr. Phaiboon telah dengan jelas merugikan Pemohon Peninjauan Kembali termasuk pemilik kapal yang sah yaitu Nyonya Wanpen Janarnont tersebut.

3. Putusan Berdasarkan Keyakinan tanpa Didukung Alat Bukti Lain

Akibat kekhilafan dan kekeliruan serta error facti oleh Judex facti Pengadilan Tinggi Surabaya dan MARI hanya berkeyakinan tanpa didukung dengan keterangan saksi - saksi dan bukti - bukti surat di - persidangan, maka Pemohon Peninjauan Kembali telah membuat kerugian besar kepada pemilik kapal MV Siriwanphen yang sebenarnya yaitu Nyonya Wanpen Jongarnont (sesuai bukti-bukti

${ }^{54}$ Salinan Putusan Mahkamah Agung Nomor 84 PK/Pid/2005 
surat PK.1, PK.2, PK.3, PK.4, PK.5, terlampir). Dimana Pemohon Peninjauan Kembali selaku Nakhoda memasuki perairan wilayah Indonesia (Laut Jawa) sama sekali tidak diketahui dan atau tanpa seijin/sepengetahuan pemilik kapal MV Siriwanphen yaitu Nyonya Wanpen Jongarnont, bukanlah phaiboon sebagaimana dikatakan oleh Pemohon Peninjauan Kembali di persidangan tingkat pertama. Dimana kapal MV Siriwanphen sesuai dengan izin Pelayaran dan Izin Perikanan hanya dapat berlayar memasuki perairan wilayah Malaysia dan Thailand sesuai bukti-bukti surat (novum PK. 4) terlampir terjemahan Bahasa Indonesia oleh Penterjemah tersumpah dan dibuat dihadapan Pejabat yang berwenang di Negara Thailand dan kemudian dilegalisir oleh kedutaan Besar RI di Bangkok Thailand.

Akibat kelalaian dan kealpaan Pemohon Peninjauan Kembali memasuki perairan wilayah Indonesia (Laut Jawa) tanpa seizin/sepengetahuan Pemilik kapal MV Siriwanphen sesuai buktibukti Kepemilikan Kapal (novum) PK.2, PK.3, PK. 4, PK.5 terlampir atas nama Nyonya Wanpen Jongarnont maka tanggung jawab pidana akibat kelalaian dan kealpaan Pemohon Peninjauan Kembali, Pemohon Peninjauan Kembali saat ini sedang melaksanakan putusan sesuai dengan peraturan dan perundangundangan yang berlaku di Indonesia. Karena hukuman pidana sedang/telah dilaksanakan oleh Pemohon Peninjauan Kembali, maka menurut hukum pula 1 (satu) buah Kapal MV Siriwanphen dan 1 (satu) bundel dokumen kapal harus dikembalikan kepada pemiliknya yaitu Nyonya Wanpen Jongarnont di negara Thailand sesuai bukti-bukti baru dalam permohonan Peninjauan Kembali ini.

Pertimbangan hukum Judex facti Pengadilan Tinggi Surabaya dan Putusan MARI sama sekali tidak mempertimbangkan keterangan saksi-saksi Sampumsak, Yau Pomee (ABK Kapal MV Siriwanphen warga negara Thailand ) serta bukti-bukti surat yang diajukan oleh Jaksa Penuntut Umum di persidangan.

4. Tentang Putusan Pengadilan Negeri Gresik

Pertimbangan hukum Pengadilan Negeri Gresik sudah menilai semua fakta-fakta hukum maupun keterangan saksi-saksi dibawah sumpah dan keterangan Pemohon Peninjauan Kembali mengenai 
barang bukti Kapal MV Siriwanphen di persidangan secara baik, benar, dan sempurna serta sudah tepat menurut hukum acara pidana.

Pertimbangan hukum tersebut adalah bahwa kapal MV Siriwanphen bukanlah kapal penangkap ikan dan pada saat kapal MV Siriwanphen ditangkap oleh Kapal patroli TNI Angkatan Laut KRI Tanjung Dalpele-972, kapal MV Siriwanphen tidak melakukan penangkapan, pembelian dan pengangkutan ikan dari perairan Indonesia (Laut Jawa) tapi saat itu hanya melakukan transfer, sehingga menurut hukum Negara Indonesia tidak dirugikan (lihat putusan PN Gresik alinea terakhir halaman 9 sampai alinea ke- 1 halaman 12). Sehingga berdasarkan hal tersebut sudah tepat Pengadilan Negeri Gresik dalam putusannya menyatakan 1 ( satu ) buah kapal MV Siriwanphen dan 1 (satu) bundel Dokumen kapal sesuai ketentuan Pasal 29 Undang - undang No. 9 tahun 1985 tidaklah harus dirampas untuk Negara.

Dengan demikian, maka Judex facti Pengadilan Tinggi Surabaya dan MA telah melakukan kekhilafan dan kekeliruan serta melakukan error facti dalam menilai keterangan saksi- saksi dan bukti-bukti surat serta fakta-fakta hukum yang terungkap di persidangan tingkat pertama tersebut.

Dengan demikian, maka menurut hukum acara pidana, patutlah bagi Majelis Hakim Agung pada tingkat Pemeriksaan Peninjauan Kembali untuk membatalkan putusan Judex facti Pengadilan Tinggi Surabaya dan MARI yang menyatakan 1 (satu) unit Kapal MV Siriwanphen dan 1 (satu) bundle Dokumen kapal MV Siriwanphen di rampas untuk Negara Indonesia untuk selanjutnya memutuskan bahwa 1 (satu) unit kapal MV Siriwanphen dan 1 (satu) bundel Dokumen kapal MV Siriwanphen harus dikembalikan kepada pemilik asli yaitu: Nyonya Wanpen Jongarnont warga negara Thailand.

\section{Implementasi Pembuktian Illegal Fishing dalam Putusan Mahkamah Agung No. 84 PK/Pid/2005}

\section{Detulisan Pembuktian}

Pembuktian berarti memperkuat kesimpulan dengan syaratsyarat bukti yang sah. Seorang penggugat wajib memberikan buktibukti yang terkait dalam perkara yang diajukan. Serta wajib 
menghadirkan minimal dua orang saksi yang sah dan yang berkompeten dalam perkara tersebut. Sebagaimana telah dijelaskan dalam Kitab Undang-Undang Hukum Acara Perdata (KUHAP) Nomor 8 Tahun 1981 Pasal 185 ayat (2) bahwa: "Keterangan seorang saksi saja tidak cukup untuk membuktikan bahwa terdakwa bersalah terhadap perbuatan yang didakwakan kepadanya." 55

Sedangkan dalam Pasal 99 ayat (2) huruf e Undang-Undang Nomor 21 Tahun 1992 Tentang Pelayaran yang menjelaskan bahwa: penyidik meminta keterangan dan alat bukti dari orang atau sehubungan dengan tindak pidana di bidang pelayaran". ${ }^{56}$

Jaksa Penuntut Umum sama sekali tidak dapat/tidak sanggup membuktikan siapa pemilik kapal yang sesungguhnya sesuai suratsurat bukti. Karena Jaksa Penuntut Umum tidak menghadirkan pemilik Kapal MV Siriwanphen (Phaiboon) di persidangan untuk dijadikan sebagai saksi, guna menerangkan benar tidaknya Phaiboon adalah pemilik Kapal dan juga apakah benar/tidaknya Phaiboon yang menyuruh dan atau memerintahkan Pemohon Peninjauan Kembali untuk memasuki wilayah perairan Indonesia (laut Jawa) untuk mentransfer, pemuatan, dan pembelian ikan.

Kalaupun benar menurut hukum Phaiboon adalah pemilik kapal MV Siriwanphen dan menyuruh/memerintahkan Pemohon Peninjauan Kembali melakukan pelayaran memasuki wilayah perairan Indonesia, maka tanggung jawab pidana bukan saja pada PemohonPeninjauan Kembali, akan tetapi Phaiboon selaku pemilik kapal juga harus ikut turut serta melakukan kejahatan perikanan.

Oleh karena Jaksa Penuntut Umum tidak sanggup menghadirkan pemilik Kapal (Phaiboon) di persidangan sebagaimana tersebut di atas, maka Pengadilan Tinggi Surabaya dan MARI melakukan kekhilafan dan kekeliruan atau error facti. ${ }^{57}$

\section{Dasar Hukum Pembuktian}

Dalam perkara pidana, setiap saksi sekaligus dianggap cakap (competend) dan dapat dipaksa (compellable). Berarti menjadi saksi dalam perkara pidana merupakan kewajiban hukum (legal

\footnotetext{
${ }^{55}$ Kitab Undang-Undang Hukum Acara Perdata (KUHAP) Nomor 8 Tahun 1981

56 Undang-Undang Nomor 21 Tahun 1992 Tentang Pelayaran

57 Salinan Putusan Mahkamah Agung Nomor 84 PK/Pid/2005, 7-8
} 
obligation), dan bagi yang tidak menaati (comply) dapat dipaksa dengan jalan membawanya dengan paksa ke persidangan, yang dikenal dengan sistem subpoena. ${ }^{58}$

Setiap orang yang mendalilkan bahwa ia mempunyai sesuatu hak, atau guna meneguhkan haknya sendiri maupun membantah suatu hak orang lain, menunjuk pada suatu peristiwa, diwajibkan membuktikan adanya hak dan peristiwa tersebut ${ }^{59}$ (Pasal 183 dan Pasal 184 KUHAPidana). Sebab itu, pembuktian dapat diartikan sebagai upaya memberi kepastian dalam arti yuridis, memberi dasardasar yang cukup kepada hakim tentang kebenaran dari suatu peristiwa yang diajukan oleh oihak yang berperkara secara formil, artinya terbatas pada bukti-bukti yang diajukan dalam persidangan.

Dalam hal ini yang harus membuktikan, yakni yang berkepentingan tidak lain adalah penggugat dan tergugat, berkepentingan bahwa gugatannya dikabulkan atau ditolak. Yang mencari kebenaran dan menetapkan atau mengkonstatir peristiwanya adalah hakim. ${ }^{60}$

Dalam Pasal 183 KUHAP jo. 294 HIR ditentukan bahwa hakim tidak boleh menjatuhkan pidana kepada seseorang, kecuali apabila dengan sekurang-kurangnya dua alat bukti yang sah ia memperoleh keyakinan bahwa suatu tindak pidana benar-benar terjadi dan bahwa terdakwalah yang bersalah melakukannya.

Patut dicermati juga penjelasan dalam pasal itu menegaskan bahwa putusan hakim adalah kebenaran, keadilan, dan kepastian hukum. Ini menjadi nyata sejalan dengan tujuan hukum acara pidana untuk menemukan kebenaran hukum yang pasti, dan sekaligus itulah yang menjadi keadilan. Sekali lagi, itu tampak sangat penting karena menjadi karakter khas ilmu hukum acara pidana. Esensi makna putusan hakim itu adalah ditemukannya kebenaran, keadilan, dan kepastian hukum dalam satu kesatuan atau dengan kata lain, di dalam

58 Yahya Harahap, Hukum Acara Perdata Gugatan Persidangan Penyitaan Pembuktian Dan Putusan Pengadilan (Jakarta: Sinar Grafika, 2005), 625.

${ }^{59}$ Sophar Maru Hutagalung, Praktik Pengadilan Perdata Teknis Menangani Perkara di Pengadilan (Jakarta: Sinar Grafika, 2010), 81.

${ }^{60} \mathrm{lbid}$. 
putusan hakim itu ada tiga hal yang mengkristal jadi satu, yaitu kebenaran, keadilan, dan kepastian hukum. ${ }^{61}$

Sistem pembuktian yang dianut ketentuan Pasal 183 itu bermakna bahwa keyakinan hakim ditujukan terhadap ditemukannya minimal dua alat bukti yang sah (menurut KUHAP ada lima alat bukti). Keyakinan hakim itu juga ditujukan terhadap benar terjadinya tindak pidana dan benar terdakwa yang melakukannya. Dengan demikian, titik tolak keyakinan hakim diperoleh dari dua alat bukti terjadinya tindak pidana dan dua alat bukti itu juga membenarkan pelakunya adalah terdakwa. Yang negatif terhadap undang-undang ada dua hal, yakni:

a. Alat-alat bukti minimal dua (KUHAP Pasal 184 jo. 183)

b. Pelaku tindak pidana benar dapat dihukum (KUHP pidana materiil Pasal 1 jo. Pasal 48-51 jo. Pasal 76-79). ${ }^{62}$

Pasal 159 ayat (2) KUHAP menentukan, bahwa dalam hal saksi tidak hadir meskipun telah dipanggil dengan sah dan hakim ketua sidang mempunyai cukup alasan untuk menyangka bahwa saksi itu tidak akan mau hadir, maka hakim ketua sidang dapat memerintahkan supaya saksi tersebut dihadapkan ke persidangan.

Menjadi saksi adalah suatu kewajiban setiap orang. Orang yang menjadi saksi setelah dipanggil ke suatu sidang pengadilan untuk memberikan keterangan tetapi dengan menolak kewajiban itu ia dapat dikenakan pidana berdasarkan ketentuan undang-undang yang berlaku.

Hanya sebelum bertindak, maka haruslah terlebih dahulu diperiksa, apakah saksi yang bersangkutan telah dipanggil dengan baik secara tertulis, dan jika memang ternyata demikian, maka yang menjadi persoalan adalah apakah perkara tersebut akan dilanjutkan pemeriksaannya atau tidak, hal mana akan tergantung pada banyak atau kurang pentingnya keterangan dari pada saksi yang tidak hadir tersebut. Mengenai hal ini, hakimlah yang memutuskannya. Jika diputuskan untuk menunda pemeriksaan perkara pidana tersebut,

${ }^{61}$ Nikolas Simanjutak, Acara Pidana Indonesia dalam Sirkus Hukum (Jakarta: Ghalia Indonesia, 2009), 243.

62 lbid, 244. 
dan membawanya ke muka Pengadilan, hal mana oleh hakim dimintakan pelaksanaannya pada Jaksa. ${ }^{63}$

Jika para saksi bertempat tinggal di luar Indonesia, maka hakim dapat meminta kepada seorang pejabat di negara tempat tinggal saksi itu untuk memeriksanya atau menyerahkan pemeriksaan itu kepada seorang pejabat konsuler di tempat tinggal para saksi. Berita acara itu mempunyai kekuatan yang sama dengan berita acara yang dibuat oleh hakim Indonesia. ${ }^{64}$

\section{Analisis Dasar Pertimbangan Hukum dalam Putusan Mahkamah Agung No. $84 \mathrm{PK} / \mathrm{Pid} / 2005$ tentang Pembuktian Perkara Illegal Fishing}

Bahwa pertimbangan yang mendasari putusan Pengadilan Negeri Gresik, Pengadilan Tinggi Surabaya dan putusan MARI atas keterbuktian kesalahan Pemohon Peninjauan kembali, dimana Pemohon Peninjauan Kembali selaku Nakhoda Kapal MV Siriwanphen, kapal berbendera Thailand yang digunakan untuk mengangkut atau menyimpan ikan hasil tangkapan di perairan wilayah Indonesia (laut Jawa) tidak memiliki dokumen izin pelayaran, Izin Usaha Perikanan dan Surat Penangkapan Ikan (SPI) sesuai Pasal 2 huruf a.b jo Pasal 10 ayat (1) jo Pasal 25 huruf a Undang-undang No. 9 tahun 1985 tentang Perikanan

Bahwa pertimbangan hukum Judex facti Pengadilan Tinggi Surabaya dan MARI menjatuhkan pidana kepada Pemohon Peninjauan Kembali serta memerintahkan Kapal MV Siriwanphen dirampas untuk negara, karena Pemohon Peninjauan Kembali selaku Nakhoda Kapal Siriwanphen memasuki perairan wilayah Indonesia atas suruhan dan atau perintah pemilik Kapal MV Siriwanphen yaitu Saudara Phaiboon.

Dari keterangan Pemohon Peninjauan Kembali tersebut, kemudian Judex facti Pengadilan Tinggi Surabaya maupun MARI menyatakan Kapal MV Siriwanphen adalah merupakan sarana atau alat yang dipakai untuk melakukan kejahatan. Karena itu 1 (satu) unit Kapal MV Siriwanphen dan 1 (satu) bendel dokumen kapal dirampas untuk negara.

63 Djoko Prakoso, Alat Bukti dan Kekuatan Pembuktian di dalam Proses Pidana (Yogyakarta: Liberty, 1988), 60.

${ }^{64}$ Ropaun Rambe, Hukum Acara Perdata Lengkap (Jakarta: Sinar Grafika, 2002), 44. 
Selanjutnya pertimbangan hukum yang mendasari putusan Judex facti Pengadilan Tinggi Surabaya maupun MARI hanyalah didasarkan pada keterangan Pemohon Peninjauan Kembali saja yang dijadikan sebagai bukti petunjuk, tanpa didukung oleh 2 (dua) keterangan saksi. Sedangkan kedua orang saksi yaitu: Sampumsak Neulai dan Yau Pomee termasuk bukti-bukti surat kepemilikan kapal (lihat putusan Pengadilan Negeri Gresik alinea ke-2 halaman 5 sampai alinea ke-2 halaman 6) di mana kedua saksi tersebut (ABK Kapal MV Siriwanphen) sama sekali tidak membuktikan Phaiboon adalah pemilik Kapal MV Siriwanphen, selain itu Jaksa Penuntut Umum tidak menghadirkan Phaiboon selaku pemilik kapal dalam persidangan.

Dengan demikian, menurut hukum dan Undang-undang setiap perbuatan hukum/suatu kejahatan yang dilakukan oleh seseorang dan atau bertindak atas nama Badan Hukum bukan saja pelaku yang bertanggung jawab atas perbuatannya akan tetapi pimpinannya (Phaiboon) juga harus ikut bertanggung jawab diluar sidang maupun di dalam persidangan.

Perkara lingkungan hidup agak pelik, karena berkaitan dengan subjektivitas yang amat kuat, tetapi yang paling menentukan bisa tidaknya perkara dugaan pidana lingkungan hidup itu ditentukan oleh keberanian dan kecerdasan dari unsur justice system. Dalam rumusan Pasal 87 ayat (1) Undang-Undang Nomor 32 Tahun 2009 tentang Perlindungan dan Pengelolaan Lingkungan Hidup yang berbunyi:

"Setiap penanggung jawab usaha dan/atau kegiatan yang melakukan perbuatan melanggar hukum berupa pencemaran dan/atau perusakan lingkungan hidup yang menimbulkan kerugian pada orang lain atau lingkungan hidup wajib membayar ganti rugi dan/atau melakukan tindakan tertentu."

Dalam pasal itu terdapat tiga unsur, masing-masing sebagai berikut:

1. unsur setiap penanggung jawab,

2. unsur pencemaran,

3. unsur perusakan lingkungan.

Selanjutnya dalam Pasal 1 angka 35 Undang-Undang Nomor 32 Tahun 2009 yang berbunyi:

"Izin lingkungan adalah izin yang diberikan kepada setiap orang yang melakukan usaha dan/atau kegiatan yang wajib Amdal atau UKL-UPL dalam rangka perlindungan dan pengelolaan 
lingkungan hidup sebagai prasyarat untuk memperoleh izin dan/atau kegiatan."

Jadi, unsur pencemaran itu sudah sangat jelas antara lain adanya unsur lain yang masuk ke dalam lingkungan hidup itu, dan keberadaan zat itu justru disfungsi.

Selanjutnya unsur perusakan lingkungan pembuktiannya antara lain misalnya dalam rumusan perusakan lingkungan hidup, adalah adanya subjek hukum yang dapat saja berupa lembaga, maupun badan hukum yang jelas, adanya alam sekitar yang natural, adanya perbuatan mengubah alam yang dapat mendatangkan kerugian pada pihak lain. ${ }^{65}$

Penulis menemukan banyak kekeliruan yang ada di dalam Putusan Mahkamah Agung No. 84 PK/Pid/2005. Baik dari segi proses pembuktiaannya dan penjatuhan sanksi/hukuman terhadap terdakwa Jai Hadsadee, karena sanksi/hukuman yang diberikan tidak sesuai dengan Undang-Undang yang berlaku. Dimana dijelaskan dalam Pasal 110 Undang-Undang Nomor 21 Tahun 1992 Tentang Pelayaran bahwa:

1. Nakhoda atau pemimpin kapal yang tidak mematuhi peraturanperaturan untuk menjaga ketertiban dan kelancaran lalu lintas kapal di pelabuhan sebagaimana dimaksud Pasal 40 ayat (1) dipidana dengan pidana kurungan paling lama 3 (tiga) bulan atau denda setingi-tingginya Rp. 6.000.000,- (enam juta rupiah).

2. Nakhoda atau pemimpin kapal yang berlayar tanpa memiliki Surat Izin Berlayar sebagaimana dimaksud dalam Pasal 40 ayat (2) dipidana dengan pidana kurungan paling lama 1 (satu) tahun atau denda setinggi-tingginya Rp. 24.000.000,- (dua puluh empat juta rupiah). ${ }^{66}$

Namun kenyataannya, sesuai dengan Putusan Mahkamah Agung No. 84 PK/Pid/2005, terdakwa Jai Hadsadee justru diberi sanksi lebih dari 1 (satu) tahun. Berikut adalah sanksi yang diberikan kepada terdakwa Jai Hadsadee menurut Putusan Mahkamah Agung No. 84 $\mathrm{PK} / \mathrm{Pid} / 2005$ :

a) Menjatuhkan, pidana terhadap Terdakwa tersebut dengan pidana penjara selama 1 (satu) tahun 6 (enam) bulan

\footnotetext{
${ }^{65}$ Hartono, Penyidikan dan Penegakan Hukum Pidana Melalui Pendekatan Hukum Progresif, 61.

${ }^{66}$ Undang-Undang RI No. 21 Tahun 1992 Tentang Pelayaran
} 
b) Cek Bank Mandiri senilai Rp. 24.750.000,- ( Dua puluh empat juta tujuh ratus lima puluh ribu rupiah ) sebagai hasil lelang ikan sebanyak lebih kurang 110 ton, dirampas untuk Negara. ${ }^{67}$

\section{Analisis Hukum Islam terhadap Putusan Mahkamah Agung No. 84 PK/Pid/2005 tentang Pembuktian Perkara Illegal Fishing}

Merupakan suatu asas bahwa barang siapa yang mendalilkan sesuatu dia harus membuktikannya. ${ }^{68}$ Sehubungan dengan itu, menerjemahkan hadis Rasulullah saw tentang asas pembuktian di bawah ini, tidak bisa dikatakan "bukti dibebankan kepada penggugat."

Dari Abdullah bin Abbas, Rasulullah saw telah bersabda:

"Jika gugatan seorang dikabulkan begitu saja, niscaya akan banyaklah orang yang menggugat hak atau hartanya terhadap orang lain tetapi (ada cara pembuktiannya) kepada yang menuntut hak (termasuk yang membantah hak orang lain dan menunjuk suatu peristiwa tertentu) dibebankan untuk membuktikan dan (bagi mereka yang tidak mempunyai bukti lain) dapat mengingkarinya dengan sumpah." HR. Bukhary dan Muslim dengan sanad sahih. ${ }^{69}$

Sebagaimana asas tersebut, penulis menyampaikan bahwa seharusnya seorang Jaksa sebagai penuntut umum menghadirkan saksisaksi yang bersangkutan dalam perkara illegal fishing ini, yaitu menghadirkan saksi pemilik kapal yang digunakan oleh tergugat untuk membuktikan benar tidaknya kapal tersebut miliknya atau tidak yang telah digunakan untuk melakukan perbuatan pidana yaitu illegal fishing di perairan Jawa (Gresik). Karena menurut hukum dan Undang-Undang setiap perbuatan hukum/ suatu kejahatan yang dilakukan oleh seseorang dan atau bertindak atas nama Badan Hukum bukan saja pelaku yang bertanggung jawab atas perbuatannya akan tetapi pimpinannya juga harus ikut bertanggung jawab di luar sidang maupun di dalam persidangan.

\footnotetext{
${ }^{67}$ Salinan Putusan Mahkamah Agung Nomor 84 PK/Pid/2005

68 Zaenudin A. Naufal, Pembaharuan Hukum Acara Peradilan Agama (Bogor: Ghalia Indonesia, 2012), 174.

${ }^{69}$ Rasyid A. Roihan, Hukum Acara Peradilan Agama (Jakarta: Raja Grafindo Persada, 2006), 156.
} 


\section{Simpulan}

Pada perkara putusan Mahkamah Agung nomor $84 \mathrm{PK} / \mathrm{Pid} / 2005$, dalam proses pembuktian di persidangan terjadi adanya kekeliruan. Di mana pihak penggugat yaitu Jaksa Penuntut Umum tidak dapat menghadirkan saksi pemilik kapal yang digunakan oleh terdakwa Jai Hadsadee yaitu Phaibon sebagai pemilik kapal MV. Siriwanphen. Karena seharusnya pihak penggugat wajib memberikan bukti-bukti minimal dua alat bukti yaitu bukti saksi yang berkaitan langsung dengan masalah tersebut. Sebagaimana disebutkan oleh Pasal 183 KUHAP.

Menurut hukum dan Undang-Undang, setiap perbuatan hukum/suatu kejahatan yang dilakukan oleh seseorang dan atau bertindak atas nama Badan Hukum bukan saja pelaku yang bertanggungjawab atas perbuatannya akan tetapi pimpinannya (Phaibon) juga harus ikut bertanggungjawab di luar sidang maupun di dalam persidangan.

Pada perkara putusan Mahkamah Agung nomor $84 \mathrm{PK} / \mathrm{Pid} / 2005$, dimana hakim tidak menghiraukan kekeliruan yang dilakukan oleh Jaksa Penuntut Umum yakni tidak dapat menghadirkan saksi pemilik kapal MV. Siriwanphen. Hal ini tidak sesuai dengan pendapat Ibnu Qayyim al-Jauziyah dan pendapat para ulama fiqh yang lain. Serta tidak sesuai dengan al-Qur'an surat al-Baqarah ayat 282, dan surat al-Thalaq ayat 2. Karena seharusnya Jaksa Penuntut Umum dapat menghadirkan Phaibon sebagai saksi di dalam persidangan.

\section{Daftar Rujukan}

A., Naufal Zaenudin. Pembaharuan Hukum Acara Peradilan Agama. Bogor: Ghalia Indonesia, 2012.

Anshoruddin. Hukum Pembuktian Menurut Hukum Acara Islam dan Hukum Positif. Yogyakarta: Pustaka Pelajar, 2004.

Ash Shiddieqy, Muhammad Hasbi. Peradilan dan Hukum Acara Islam. Semarang: PT. Pustaka Rizki Putra, 1997.

Aziz, Dahlan Abdul. Ensiklopedi Hukum Islam. Jakarta: Ichtiar Baru Van Hoeve, 1996.

Depag RI. Al-Qur'an dan Terjemahannya. Jakarta: CV. Diponegoro, 2000.

Djalil, Basiq. Peradilan Islam. Jakarta: Amzah, 2012. 
Hamid, Hamrat dan Harun M. Husein. Pembahasan Permasalahan KUHAP Bidang Penyidikan. Jakarta: Sinar Grafika, 1992.

Hamzah, Andi. Hukum Acara Pidana Indonesia Edisi Kedua. Jakarta: Sinar Grafika, 2009.

Harahap, Yahya. Hukum Acara Perdata Gugatan Persidangan Penyitaan Pembuktian dan Putusan Pengadilan. Jakarta: Sinar Grafika, 2005.

Hartono. Penyidikan \& Penegakan Hukum Pidana Melalui Pendekatan Hukum Progresif. Jakarta: Sinar Grafika, 2010.

Hutagalung, Sophar Maru. Praktik Pengadilan Perdata Teknis Menangani Perkara di Pengadilan. Jakarta: Sinar Grafika, 2010.

Jauziyah (al-), Ibnu Qayyim. Hukum Acara Peradilan Islam. Yogyakarta: Pustaka Pelajar, 2006.

Lubis, Sulaikin. Hukum Acara Perdata Peradilan Agama di Indonesia. Jakarta: Kencana Prenada Media Group, 2005.

Madzkur, Muhammad Salam. al-Qadha fi al-Islam, terj. Imran A.M., Surabaya: Bina Ilmu, 1982.

Mujahidin, Ahmad. Pembaharuan Hukum Acara Peradilan Agama. Bogor: Ghalia Indonesia, 2012.

Mukhlas, Oyo Sunaryo. Perkembangan Peradilan Islam. Bogor: Ghalia Indonesia, 2011.

Muslih, Ahmad Wardi. Hukum Pidana Islam. Jakarta: Sinar Grafika Offset, 2005.

Prakoso, Djoko. Alat Bukti dan Kekuatan Pembuktian di dalam Proses Pidana. Yogyakarta: Liberty, 1988.

Roihan, Rasyid A. Hukum Acara Peradilan Agama. Jakarta: Raja Grafindo Persada, 2006.

Ropaun, Rambe. Hukum Acara Perdata Lengkap. Jakarta: Sinar Grafika, 2002.

Simanjutak, Nikolas. Acara Pidana Indonesia dalam Sirkus Hukum. Jakarta: Ghalia Indonesia, 2009.

Yudowidagdo, Hendrastanto. Kapita Selekta Hukum Acara Pidana di Indonesia. Jakarta: Melton Putra, 1987. 
Burhanuddin, Andi Iqbal. "Detik News", http://info-budidaya.blogspot.com /2012/03/illegal-fishing-antara-kesadarandan.html. (16 Desember 2012)

Kitab Undang-Undang Hukum Acara Pidana

Salinan Putusan Mahkamah Agung Nomor 84 PK/Pid/2005

Undang-Undang No. 21 Tahun 1992 Tentang Pelayaran

354 Fifin Inbatun Hasanah | Error Facti Pada Pembuktian Illegal 